\title{
STUDI POTENSI PEMBENTUKAN BIOGAS DARI SAMPAH MAKANAN DAN KO-SUBSTRAT FESES SAPI UNTUK ENERGI LISTRIK ALTERNATIF: STUDI KASUS DI UNIVERSITAS ANDALAS
}

\section{The Study of Potential Biogas Formation from Food Waste and Co-Substrates of Cow Feces for Alternatives Electrical Energy: Case Study In Andalas University}

\author{
Ardinal ${ }^{1^{*}}$, Rima Senditya Gewe ${ }^{2}$, Slamet Raharjo ${ }^{3}$, dan Iskandar $\mathbf{R}^{3}$ \\ ${ }^{1}$ Balai Riset dan Standardisasi Industri Padang \\ Jurusan Teknik Lingkungan, Universitas Andalas Padang \\ ${ }^{3} J u r u s a n$ Teknik Mesin, Universitas Andalas Padang \\ *e-mail: ardinal_ok@yahoo.co.id
}

Diterima: 16 Juli 2015, revisi akhir: 18 Oktober 2015 dan disetujui untuk diterbitkan: 5 Desember 2015

\begin{abstract}
ABSTRAK
Bahan baku potensial pembentukan biogas melalui pengolahan anaerobik yang tersedia di Kampus Universitas Andalas (Unand) Padang yakni sampah makanan kantin dan feses sapi. Studi ini bertujuan untuk melihat pengaruh penambahan feses sapi dalam pembentukan biogas dari sampah makanan menggunakan floating drum digester yang dikondisikan duplo. Waktu retensi 20 hari dan $\mathrm{pH}$ bahan isian dikondisikan dengan menambahkan batu kapur. Variasi rasio komposisi bahan isian berupa sampah makanan dan feses sapi yakni 100:0 (digester kontrol), 75:25 (digester uji 1 dengan rasio C/N 30) dan 50:50 (digester uji 2 dengan rasio C/N 25). Hasil penelitian menunjukkan volume kumulatif biogas digester kontrol yakni 0,927 liter dengan estimasi gas metana $591,885 \mathrm{mg} / \mathrm{L}$ serta tidak menyala saat dibakar. Volume kumulatif biogas digester uji 1 yakni 13,715 liter dengan estimasi konsentrasi gas metana 15502,61 mg/L serta warna nyala biru kemerahan. Volume kumulatif biogas digester uji 2 yakni 10,18 liter dengan estimasi konsentrasi gas metana $23297,59 \mathrm{mg} / \mathrm{L}$ serta warna nyala biru.
\end{abstract}

Kata Kunci: Sampah makanan, feses sapi, biogas, konversi biogas, energi listrik

\section{ABSTRACT}

The potential raw materials for biogas formation through anaerobic treatments available on the campus of Andalas University (Unand) in Padang are the cafeteria's food waste and cow feces. This study was aimed to look at the effect of cow feces in the formation of biogas from food waste that used a floating drum digester which was conditioned twice. Retention time was 20 days and the $\mathrm{pH}$ of packing material was conditioned by adding limestone. The ratio variation of packing materials composition such as food waste and cow feces were 100:0 (control digester), 75:25 (test 1 digester with a $\mathrm{C} / \mathrm{N}$ ratio 30) and 50:50 (test 2 digester with a $\mathrm{C} / \mathrm{N}$ ratio 25). The results showed that cumulative volume of biogas in control digester was 0.927 liters with methane gas estimated $591.885 \mathrm{mg} / \mathrm{L}$ and did not light when burned. The cumulative volume of biogas in test 1 digester was 13.715 liters with methane gas estimated was $15502.61 \mathrm{mg} / \mathrm{L}$ with the reddish color of blue flame. The cumulative volume of biogas in test 2 digester was 10.18 liters with concentration of methane gas was estimated $23297.59 \mathrm{mg} / \mathrm{L}$ and with blue color flame.

Keywords: Food waste, cow feces, biogas, biogas conversion, electrical energy

\section{PENDAHULUAN}

Universitas Andalas (Unand) merupakan kampus hijau yang menduduki peringkat keempat dan peringkat 88 dunia versi UI Green Metric World Class University. Kegiatan yang dilakukan berupa pemanfaatan dan penelitian dalam bidang energi baru terbarukan (EBT). Kegiatan lain yang dilakukan berupa peningkatan penghijauan dan pengelolaan sampah terpadu di lingkungan kampus (Berita Unand, 2014).

Pengelolaan sampah terpadu di lingkungan kampus Unand didukung dengan keberadaan Pusat Pengolahan 
Sampah Terpadu (PPST). Pengolahan sampah di PPST dilakukan untuk meminimalisir jumlah sampah yang akan di buang ke TPA. Sampah yang diolah di PPST yakni sampah organik dan anorganik. Pengolahan sampah anorganik yang dilakukan berupa pemilahan dan pengolahan serta pendaur ulangan agar dapat dimanfaatkan kembali. Sampah organik diolah di PPST secara aerobik menggunakan rotary-kiln composter untuk menghasilkan kompos. Bahan baku yang digunakan dalam pembuatan kompos yakni sampah halaman, sampah makanan dan feses sapi. Persen pelayanan untuk pengolahan sampah makanan yang dilakukan di PPST yang notabene berasal dari kantin Unand baru mencapai 35\%. Sisa sampah makanan sekitar $65 \%$ masih belum terolah karena keterbatasan teknologi yang tersedia (PPST Unand, 2015).

Alternatif pengolahan sampah makanan yang dapat dilakukan yakni secara anaerobik. Produk yang dihasilkan lebih berdaya guna dibandingkan proses aerobik. Hasil akhir yang diperoleh berupa kompos dan energi terbarukan dalam bentuk gas metana yang dikenal dengan biogas (Tchobanoglous, 1993). Biogas adalah gas yang dihasilkan dari proses penguraian bahan organik oleh mikroorganisme dalam keadaan anaerobik (Wahyuni, 2011).

Sampah makanan merupakan bahan potensial dengan ketersediaan yang cukup banyak di Kampus Unand. Berdasarkan hasil penelitian Chania (2010), komposisi sampah makanan yang dihasilkan di Unand sekitar $26,6 \%$ dengan potensi daur ulang $98 \%$ untuk diolah menjadi kompos dan biogas. Persentase sampah makanan yang cukup besar didukung keberadaan 51 kantin yang beroperasional di setiap hari kerja di kawasan Kampus Unand. Wardana (2012) dalam penelitiannya menyatakan bahwa limbah-limbah kantin memiliki potensi untuk menjadi sumber energi terbarukan, yaitu biogas. Bahan organik potensial lainnya untuk diolah menjadi biogas yang tersedia di kawasan kampus Unand yakni feses sapi dari UPT Peternakan Unand. Pengkajian uji pembentukan biogas dari campuran kedua bahan organik tersebut belum pernah dilakukan sehingga perlu diteliti lebih lanjut.
Pengkajian terkait uji pembentukan biogas yang dilakukan menggunakan floating drum digester dengan pengkondisian $\mathrm{pH}$ melalui penambahan batu kapur. Pengujian kondisi awal bahan isian digester yakni kadar air, rasio $\mathrm{C} / \mathrm{N}$, dan $\mathrm{pH}$. Pengujian yang dilakukan untuk kualitas dan kuantitas biogas yang dihasilkan yakni komposisi gas, warna nyala, dan volume kumulatif gas. Variasi komposisi bahan isian yang digunakan ditentukan berdasarkan rasio C/N bahan isian (Culp, W. Jr. Archie, 1977). Dengan penelitian ini diharapkan menjadi acuan dalam pemanfaatan sampah makanan dan feses sapi sebagai bahan pembentukan biogas. Konversi biogas ke energi listrik dapat dimanfaatkan untuk memenuhi kebutuhan listrik PPST Unand.

\section{Sampah Organik dan Biogas}

Kata kunci dari biogas adalah bahan bakar gas terbarukan hasil fermentasi bahan organik oleh mikroorganisme anaerobik. Peranan bakteri pengurai dan kondisi anaerobik serta ketersediaan bahan organik yang mendukung merupakan kunci dari pengolahan secara anaerobik. Proses pembentukan biogas menggunakan alat yang disebut reaktor biogas (digester) yang dirancang kedap udara. Komposisi utama dari biogas yakni gas metana, selain itu terdapat gas lain yang dihasilkan dari proses pengolahan anaerobik. Gas metana yang terkandung dalam biogas memiliki keunggulan dibandingkan bahan bakar fosil yaitu ramah lingkungan dan dapat diperbaharui (Al Seadi, 2008). R a n g k a i a $\mathrm{n}$ reaksi kimia dalam pembentukan biogas dapat dibagi menjadi tiga tahapan utama yaitu hidrolisis, asifidikasi (pengasaman), dan metanogenesis (Arsova, 2010).

Hidrolisis adalah reaksi pemecahan molekul organik kompleks menjadi monomer terlarut. Hasil dari proses ini ditransformasi oleh mikroorganisme pembentuk asam yang dikenal dengan proses asidifikasi. Tahap asidifikasi difasilitasi oleh mikroorganisme pembentuk asam sehingga dihasilkan asam organik sederhana seperti asam asetat $\left(\mathrm{CH}_{3} \mathrm{COOH}\right)$, etanol, hidrogen $\left(\mathrm{H}_{2}\right)$ dan karbon dioksida $\left(\mathrm{CO}_{2}\right)$. Selanjutnya tahapan metanogenesis 
difasilitasi oleh mikroorganisme metanogen yang mengkonversi material terlarut menjadi metana (Arsova, 2010).

Proses pembentukan biogas memerlukan kondisi optimal yang menunjang pertumbuhan mikroorganisme anaerobik. Faktor dalam (dari digester) dan faktor luar yang dapat mempengaruhi pembentukan biogas yakni jenis bahan organik (substrat), derajat keasaman $(\mathrm{pH})$, rasio $\mathrm{C} / \mathrm{N}$, temperatur, zat toksik, pengadukan, starter dan waktu retensi (Wahyuni, 2011).

Alat yang digunakan untuk mendukung proses pembentukan biogas yakni digester. Proses anaerobik pada bahan organik yang dibantu oleh mikroorganisme anaerobik terjadi di dalam digester dan gas yang dihasilkan akan ditampung pada penampungan gas digester (Rosilawati, 2010).

\section{Sampah Makanan dan Feses Sapi Sebagai Bahan Baku Biogas}

Sampah makanan di Unand paling banyak dihasilkan oleh kegiatan komersil yakni kantin. Jumlah kantin di Kampus Unand yakni 51 kantin. Sampah makanan yang dihasilkan pada kantin ada yang dimanfaatkan untuk pakan ternak namun kebanyakan dibuang begitu saja ke tempat sampah (Chania, 2010). Penumpukan sampah makanan berdampak terhadap sanitasi seperti pertumbuhan lalat dan bau tak sedap. Teknologi yang dapat diterapkan untuk meminimalisir dampak negatif dari sampah makanan adalah pengomposan dan pembuatan biogas (Raharjo, 2012).

Feses sapi yang ada di Kampus Unand merupakan hasil dari aktivitas UPT Peternakan Unand. Jumlah ternak sapi yang dipelihara di UPT yakni 35 ekor yang terdiri atas 29 ekor sapi potong dan 6 ekor sapi perah. Kotoran sapi yang dapat dihasikan oleh seekor sapi dengan bobot $300 \mathrm{~kg}$ setiap harinya diperkirakan sebanyak $10 \mathrm{~kg} / \mathrm{hari}$. Ketersediaan feses sapi secara keseluruhan sekitar $350 \mathrm{~kg} / \mathrm{hari}$ (Berutu, 2014).

Pengolahan yang telah dilakukan oleh UPT Peternakan yakni pengolahan secara aerobik dan anaerobik. Pengomposan dilakukan di bak terbuka yang menghasilkan kompos. Pengolahan secara anaerobik dilakukan dengan menggunakan digester dan menghasilkan energi yang dapat dimanfaatkan untuk memasak dan sumber listrik untuk penerangan (UPT Peternakan, 2014).

\section{METODOLOGI PENELITIAN}

Uji pembentukan biogas menggunakan floating drum digester karena memudahkan dalam menghitung volume gas harian yang terbentuk selama proses anaerobik (Lestari, 2012). Digester terbuat dari bahan plastik dan terdapatnya batangan aluminium untuk memudahkan dalam melihat kenaikan volume penampung biogas. Perlengkapan yang ditambahkan untuk pengukuran temperatur dan tekanan dalam digester yakni termokopel serta manometer. Floating drum digester yang digunakan dapat dilihat pada Gambar 1.

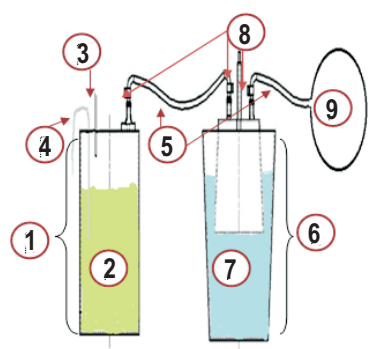
Gambar 1. Floating Drum Digester
Keterangan gambar:
1. Drum bahan isian (digester);
2. Bahan isian pembentukan biogas;
3. Selang manometer;
4. Kabel thermocouple;
5. Selang penghubung;
6. Floating drum;
7. Air;
8. Katup aliran;
9. Balon penampung.

Perakitan digester pengujian berjumlah 6 unit untuk pemrosesan 3 variasi bahan isian yang dikondisikan duplo. Bahan isian yang akan diuji pembentukan biogasnya yakni sampah makanan yang berasal dari kantin Unand berupa campuran sisa nasi, lauk pauk, sayuran dan lainnya yang telah dipilah (kecuali sisa tulang dan sampah anorganik) serta feses sapi dari UPT Peternakan. Tahapan uji pembentukan biogas adalah: 
1. Sampling sampah makanan kemudian dipilah dan diblender serta sampling feses sapi;

2. Uji karakteristik bahan secara terpisah berupa pengujian kadar air (metode gravimetri) serta rasio $\mathrm{C} / \mathrm{N}$ (uji karbon dengan metode askorbat, uji nitrogen dengan destruksi, destilasi dan titrasi);

3. Perakitan floating drum digester,

4. Penentuan komposisi berdasarkan hasil pengujian karakteristik bahan isian digester;

5. Pengoperasian digester, dilakukan pemantauan temperatur (termokopel), tekanan (manometer) dan kenaikan volume penampung biogas (meteran);

6. Pengujian pada akhir proses terhadap biogas yang dihasilkan berupa uji warna nyala dan uji hidrokarbon (absorban) untuk estimasi konsentrasi gas metana;

7. Prediksi potensi biogas berdasarkan ketersediaan bahan isian di kampus Unand untuk dikonversi menjadi energi listrik;

8. Analisis serta pembahasan sesuai hasil penelitian.

Diagram alir penelitian dapat dilihat pada Gambar 2.

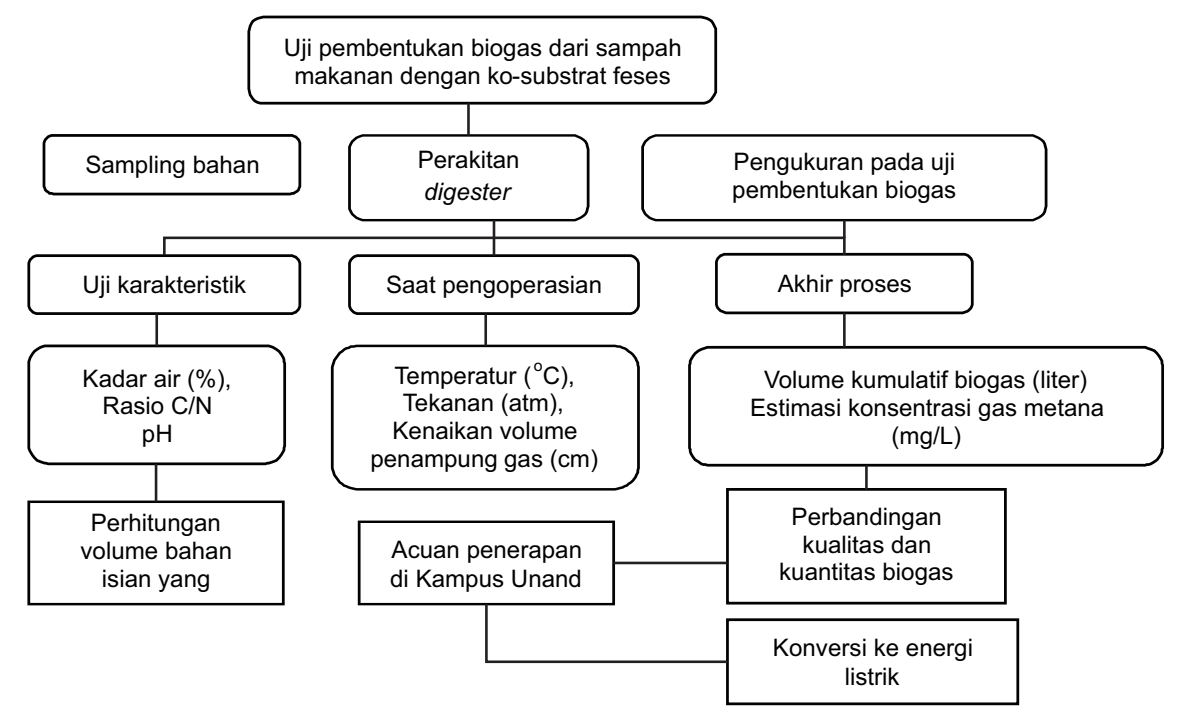

Gambar 2. Diagram Alir Penelitian

Rumus yang digunakan dalam perhitungan uji pembentukan biogas diantaranya:

1. Perhitungan komposisi bahan isian campuran, yakni:

$$
\mathrm{C} / \mathrm{N}=\frac{\mathrm{X}_{1} \mathrm{X}_{2}+\mathrm{Y}_{1} \mathrm{Y}_{2}}{\mathrm{X}_{2}+\mathrm{Y}_{2}}
$$

Keterangan:

$\mathrm{C} / \mathrm{N}$ : nilai rasio $\mathrm{C} / \mathrm{N}$ yang diinginkan

$\mathrm{X}_{1}$ : nilai rasio $\mathrm{C} / \mathrm{N}$ sampah kantin

$\mathrm{X}_{2}$ : sampah kantin yang digunakan (liter)

$Y_{1}$ : nilai rasio $C / N$ kotoran sapi

$Y_{2}$ : feses sapi yang digunakan (liter)

2. Perhitungan volume biogas, yakni:

$$
\begin{aligned}
\mathrm{V}_{\text {bioges }} & =\mathrm{V}_{\text {kercuat terpancumg }}=\frac{1}{3} \pi t\left(R^{2}+R t+r^{2}\right) \\
\mathrm{R} & =\frac{\mathrm{r} \cdot \mathrm{t}}{\mathrm{x}}+\mathrm{r}
\end{aligned}
$$

Keterangan:

$\mathrm{V}_{\text {biogas }}=$ volume biogas $(\mathrm{ml})$;

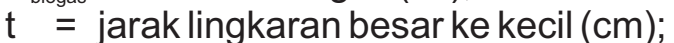

$\mathrm{R}=$ jari-jari lingkaran besar $(\mathrm{cm})$;

$r=$ jari-jari lingkaran kecil $(\mathrm{cm})$;

$\mathrm{x}=$ beda ketinggian $(\mathrm{cm})$.

3. Rumus konversi hasil pengukuran hidrokarbon untuk estimasi konsentrasi metana dalam biogas, yakni:

C metana $(\mathrm{mg} / \mathrm{L})=$ konsentrasi $\mathrm{HC}$ total $x \quad\{$ Mr Metana/MrToluena\}

4. Konversi gas metana dalam biogas menjadi energi listrik, yakni:

a. Massa gas metana dalam biogas (berdasarkan penelitian Waskito, 2011)

Massa metana $(\mathrm{kg})=\{$ Vol. gas metana (L) x konsentrasi(mg/L)\}/ $\left\{10^{6}(\mathrm{~kg} / \mathrm{mg})\right\}$

b. Konversi gas metana ke energi listrik 1) Konversi massa metana ke kJ 
$\mathrm{kJ}=$ massa gas metana $(\mathrm{kg}) \times$ faktor konversi $(55.529 \mathrm{~kJ} / \mathrm{kg})$

*faktor konversi berdasarkan Culp, W. Jr. 1977 yakni $55.529 \mathrm{~kJ} / \mathrm{kg}$

2) Konversi kJ ke potensi listrik (kWh)

$\mathrm{kWh}=\frac{\mathrm{kj}}{\text { faktor konversi }(3600 \mathrm{~kJ} / \mathrm{kWh}}$

3) Energi listrik hasil konversi (kWh)

$\mathrm{kWh}=\mathrm{kWh}$ potensi $\mathrm{x}$ faktor koreksi $(0,8) x$ efisiensi alat $(39,8 \%)$ $\mathrm{x}$ koef. koleksi biogas (50\%)

\section{HASIL DAN PEMBAHASAN}

Uji pembentukan biogas menggunakan floating drum digester skala laboratorium dengan sistem batch untuk suplai bahan isian. Bahan isian berupa sampah makanan dan feses sapi diuji karakteristiknya untuk menentukan komposisi bahan isian yang digunakan. Hasil pengujian karakteristik bahan dapat dilihat pada Tabel 1 .

Tabel 1. Hasil Uji Karakteristik Bahan Isian

\begin{tabular}{lccc}
\hline \multirow{2}{*}{ Pengujian } & \multicolumn{2}{c}{ Bahan Isian } & $\begin{array}{c}\text { Kondisi } \\
\text { Optimum }\end{array}$ \\
\cline { 2 - 3 } & $\begin{array}{c}\text { Sampah } \\
\text { Makanan }\end{array}$ & $\begin{array}{c}\text { Feses } \\
\text { Sapi }\end{array}$ & \\
\hline $\begin{array}{l}\text { Kadar Air } \\
(\%)\end{array}$ & 53,14 & 50,61 & $91-93^{*}$ \\
\hline Rasio C/N & 35,70 & 13,80 & $20-30^{* *}$ \\
\hline $\begin{array}{l}{ }^{*} \text { nilai optimum dalam Mayasari, } 2010 \\
\text { ** nilai optimum dalam Fithry, 2010 }\end{array}$ \\
\hline
\end{tabular}

Tabel 2. Variasi Komposisi Bahan Isian

\begin{tabular}{lccc}
\hline \multirow{2}{*}{ Perlakuan } & \multicolumn{3}{c}{ Bahan Isian } \\
\cline { 2 - 4 } & Kontrol & Uji 1 & Uji 2 \\
\hline Kondisi C/N & 35,7 & 30 & 25 \\
\hline $\begin{array}{l}\text { Volume sampah } \\
\text { makanan (liter) }\end{array}$ & 10 & 7,4 & 5,1 \\
\hline $\begin{array}{l}\text { Volume feses } \\
\text { sapi (liter) }\end{array}$ & 0 & 2,6 & 4,9 \\
\hline $\begin{array}{l}\text { Rasio sampah } \\
\text { makanan : feses }\end{array}$ & $100: 0$ & $74: 26$ & $51: 49$ \\
\hline $\begin{array}{l}\text { Volume air } \\
\text { tambahan (liter) }\end{array}$ & 3,78 & 3,85 & 3,9 \\
\hline $\begin{array}{l}\text { Volume total } \\
\text { isian (liter) }\end{array}$ & 13,78 & 13,85 & 13,9 \\
\hline
\end{tabular}

Bahan isian belum mencapai kondisi optimum sehingga dilakukan penambahan air (kadar air) dan pencampuran bahan isian (rasio $\mathrm{C} / \mathrm{N}$ ). Variasi komposisi bahan isian diperoleh dari perhitungan berdasarkan hasil pengujian karakteristik yang dapat dilihat pada Tabel 2. Variasi bahan isian berupa digester kontrol, uji 1 dan uji 2 pada penelitian ini dilakukan untuk melihat pengaruh penambahan ko-substrat feses sapi terhadap proses pembentukan biogas sampah makanan.

\section{Pembentukan Biogas pada Digester Penelitian}

\section{Produksi Biogas Harian}

Produksi biogas harian merupakan jumlah biogas yang dihasilkan setiap hari berdasarkan kenaikan floating drum sebagai pengumpul gas yang dapat dilihat pada Gambar 3 (kontrol), Gambar 4 (uji 1) serta Gambar 5 (uji 2).

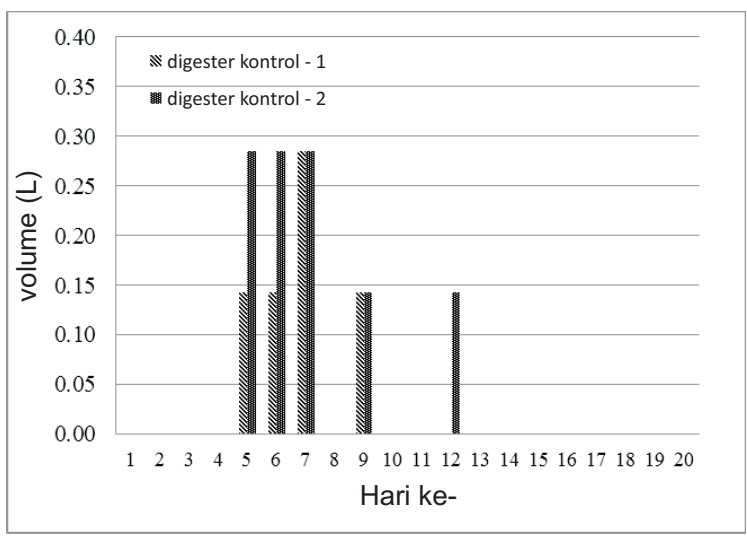

Gambar 3. Produksi Harian Digester Kontrol

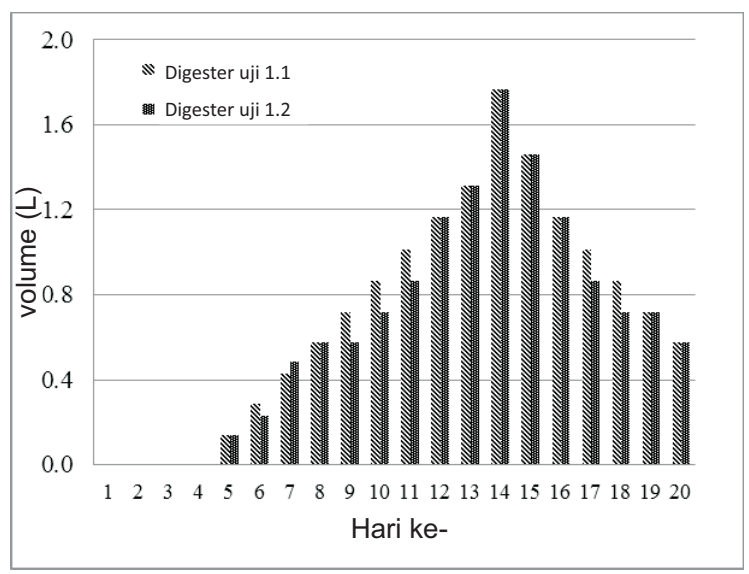

Gambar 4. Produksi Harian Digester Uji 1

Biogas yang dihasilkan pada digester kontrol sedikit karena minimnya keberadaan 
bakteri pengurai. Produksi biogas harian digester uji 1 lebih banyak daripada uji 2 karena ketersediaan sampah makanan lebih banyak sehingga proses pembentukan biogas lebih optimal. Gambar 6 menunjukkan perbandingan produksi harian biogas digester penelitian.

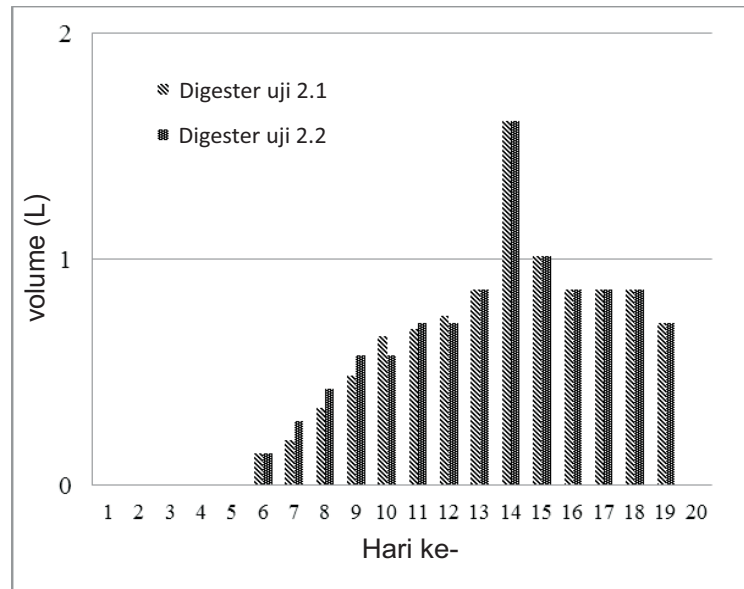

Gambar 5. Produksi Harian Digester Uji 2

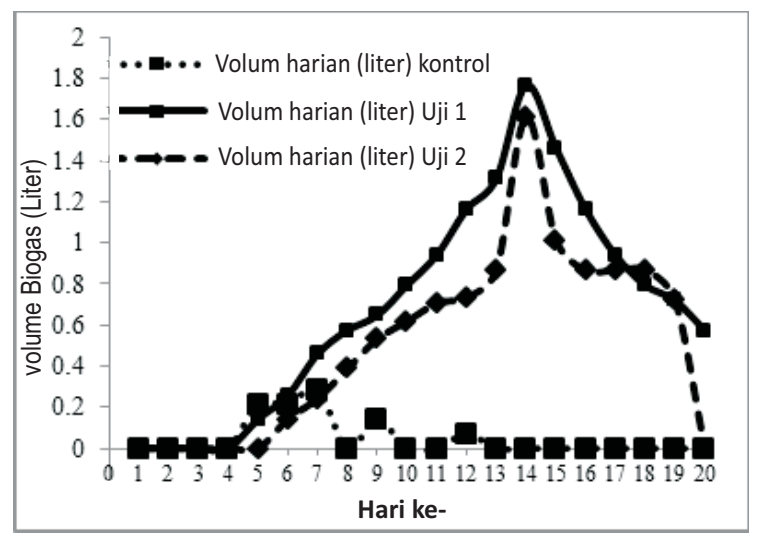

Gambar 6. Perbandingan Produksi Harian

\section{Produksi Kumulatif Biogas}

Produksi biogas kumulatif diperoleh dengan melakukan perhitungan berupa penjumlahan produksi biogas harian yang terbentuk selama proses fermentasi yang dapat dilihat pada Gambar 7 (kontrol), Gambar 8 (uji 1) serta Gambar 9 (uji 2). Kumulatif biogas digester kontrol sangat sedikit karena proses pembentukan biogas hanya berlangsung hingga hari ke 12.

Biogas kumulatif digester uji 1 lebih banyak dibandingkan uji 2, karena ketersediaan bahan organik yang akan diuraikan lebih banyak. Gambar 10 menunjukkan perbandingan produksi kumulatif biogas digester penelitian.

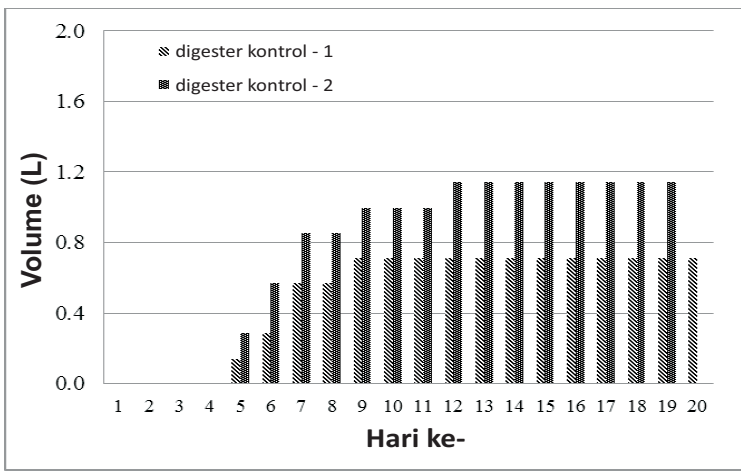

Gambar 7. Produksi Kumulatif Digester Kontrol

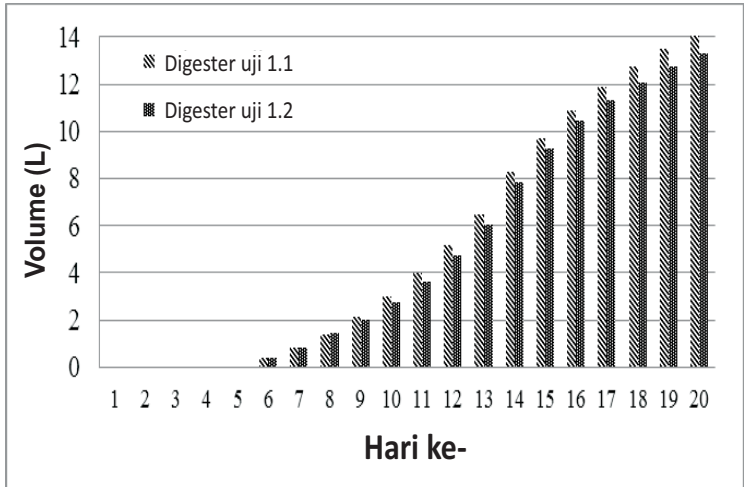

Gambar 8. Produksi Kumulatif Digester Uji 1

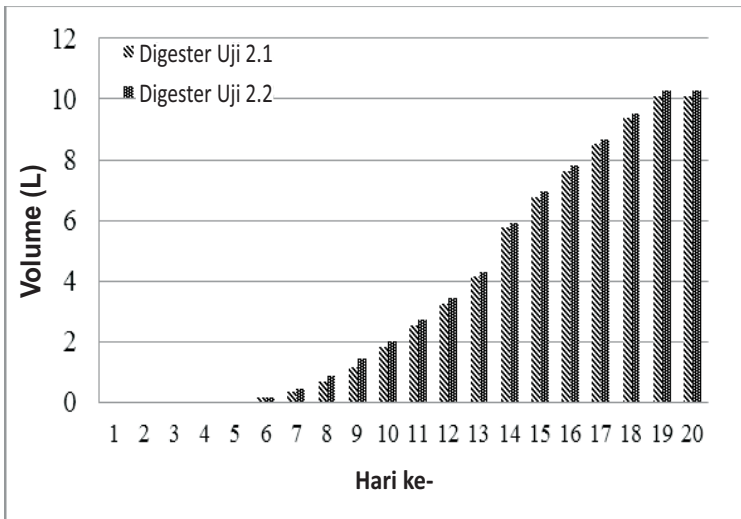

Gambar 9. Produksi Kumulatif DigesterUji 2

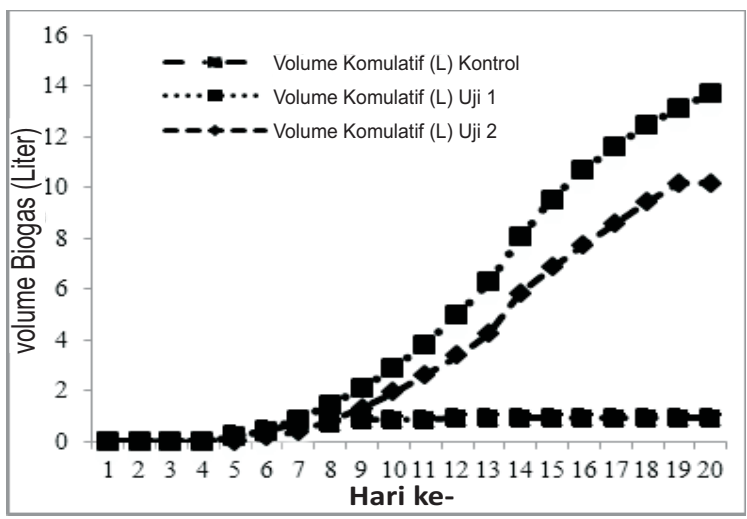

Gambar 10. Perbandingan Produksi Kumulatif 


\section{Komposisi Biogas}

Komposisi biogas digester diperoleh dengan uji kuantitatif (uji hidrokarbon) dan uji kualitatif (uji warna nyala) yang dilakukan setelah hari ke-20 pembentukan biogas. Uji kuantitatif berupa uji estimasi konsentrasi hidrokarbon yang terkandung dalam biogas dengan cara mengabsorbsi biogas menggunakan alkohol, untuk lebih jelasnya dapat dilihat pada Gambar 11.

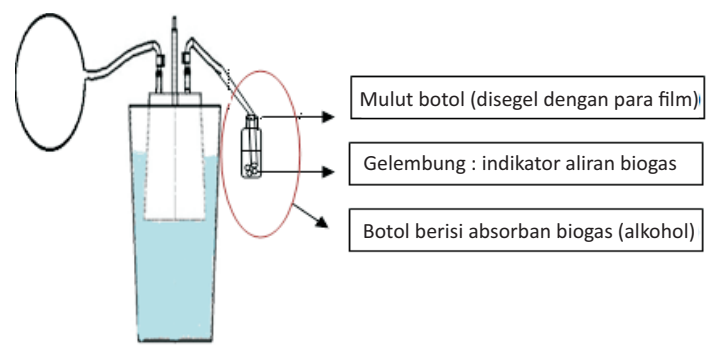

Gambar11. Skema Rangkaian Proses Absorbsi Biogas

Uji kualitatif berupa uji warna nyala dilakukan dengan menyulut biogas yang dihasilkan dengan api kemudian warna nyala api diamati. Hasil uji kualitatif dapat diilhat pada Gambar 12 (kontrol), Gambar 13 (uji 1) serta Gambar 14 (uji 2).

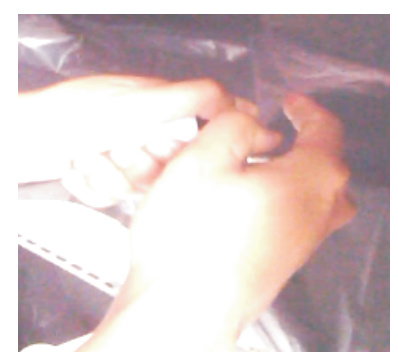

Gambar 12. Uji Warna Nyala Digester Kontrol

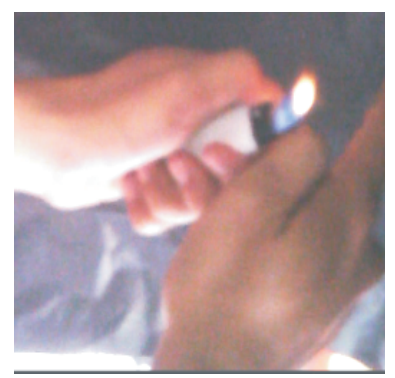

Gambar 13. Uji Warna Nyala DigesterUji 1

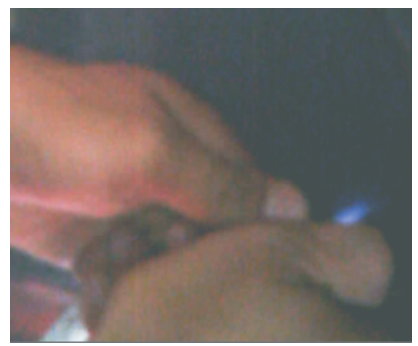

Gambar 14. Uji Warna Nyala DigesterUji 2

Digester kontrol tidak menunjukkan warna nyala ketika dibakar mengindikasikan konsentrasi gas metana rendah. Warna nyala digester uji 1 yakni biru kemerahan sedangkan digester uji 2 yakni biru. Perbedaan warna nyala mengindikasikan konsentrasi gas metana digester uji 1 lebih sedikit dibanding uji 2 .

Pengujian komposisi dilakukan untuk estimasi keberadaan serta konsentrasi gas metana dalam biogas. Pengujian berupa absorbansi metana menggunakan alkohol yang diukur konsentrasinya menggunakan spektrofotometer. Hasil uji kuantitatif biogas berupa uji hidrokarbon sebagai acuan untuk estimasi konsentrasi gas metana dapat dilihat pada Tabel 3.

Tabel 3. Hasil Uji KuantitatifBiogas

\begin{tabular}{lrr}
\hline \multicolumn{1}{c}{ Digester } & $\mathbf{H C}$ biogas (mg/L) & $\mathbf{C H}_{\mathbf{4}}$ (mg/L) \\
\hline Kontrol & 3403,34 & 591,885 \\
\hline Uji 1 & 89140,00 & 15502,605 \\
\hline Uji 2 & 133961,10 & 23297,585 \\
\hline
\end{tabular}

Estimasi konsentrasi gas metana tertinggi pada digester uji 2 yakni 23297,585 mg/L. Hasil tersebut sesuai hasil uji warna nyala yakni warna biru yang mengindikasikan dominasi gas metana.

1. Perbandingan Kuantitas dan Kualitas Biogas Digester Kontrol dan Uji Biogas yang terbentuk dari proses anaerobik menggunakan digester kontrol dan digester uji dibandingkan dengan mempertimbangkan jumlah volume biogas yang dihasilkan serta estimasi konsentrasi gas metana yang terkandung dalam biogas. Perbandingan hasil dalam uji pembentukan biogas dapat dilihat pada Tabel 4 . 
Tabel4. Hasil Uji Kuantitatif dan Kuantitatif

\begin{tabular}{lrrc}
\hline Digester & $\begin{array}{c}\text { Vol.Gas } \\
\text { (liter) }\end{array}$ & $\begin{array}{c}\text { Massa CH} \\
\text { (mg) }\end{array}$ & $\begin{array}{c}\text { Uji Warna } \\
\text { Nyala }\end{array}$ \\
\hline Kontrol & 0,927 & 548,677 & - \\
\hline Uji 1 & 13,715 & 212618,228 & $\begin{array}{c}\text { Biru } \\
\text { kemerahan }\end{array}$ \\
\hline Uji 2 & 10,18 & 237169,415 & Biru \\
\hline
\end{tabular}

Hasil yang diperoleh menunjukkan digester uji 2 mengandung massa gas metana terbanyak dengan volume gas lebih sedikit dibandingkan digester uji 1. Komposisi kedua digester uji dipertimbangkan untuk penerapan pembentukan biogas di kampus Unand berdasarkan ketersediaan bahan isian.

\section{Satuan Hasil Pembentukan Biogas}

Satuan hasil untuk pembentukan biogas berdasarkan hasil yang diperoleh maka didapatkan adalah:

1. Digester kontrol yakni $548,677 \mathrm{mg}$ $\mathrm{CH}_{4} / 10$ liter sampah makanan;

2. Digester uji 1 yakni $212618,228 \mathrm{mg}$ $\mathrm{CH}_{4} / 7,4$ liter sampah makanan $+2,6$ liter feses sapi;

3. Digester uji 2 yakni $237169,415 \mathrm{mg}$ $\mathrm{CH}_{4} / 5,1$ liter sampah makanan $+4,9$ liter feses sapi;

\section{Prediksi Konversi Biogas ke Energi Listrik}

Konversi biogas ke energi listrik yakni mengubah energi potensial yang ada dalam biogas menjadi mekanik kemudian menjadi energi listrik Teknologi yang dapat digunakan yakni gas engine $100 \mathrm{kWh}$ karena ketersediaannya di pasaran serta efisiensi hasil yang lebih besar. Hasil konversi dapat dilihat pada Tabel 5 .

Tabel5. Hasil Konversi Biogas ke Energi Listrik

\begin{tabular}{lrrrr}
\hline Digester & $\begin{array}{c}\text { Massa } \\
\mathbf{C H}_{\mathbf{4}}(\mathbf{k g})\end{array}$ & $\begin{array}{c}\text { Burning } \\
\text { Value (kJ) }\end{array}$ & $\begin{array}{c}\text { Konversi } \\
\mathbf{( k W h )}\end{array}$ \\
\hline Uji 1 & 0,213 & 13084,302 & 0,552 \\
\hline Uji 2 & 0,237 & 13253,501 & 0,582 \\
\hline
\end{tabular}

Hasil konversi biogas ke energi listrik tertinggi yakni digester uji 2 yakni 0,582 $\mathrm{kWh}$.

\section{Potensi Pemanfaatan Sampah Makanan dan Feses Sapi untuk Menghasilkan Biogas}

Potensi pemanfaatan sampah makananan dan feses sapi dapat diperkirakan berdasarkan penelitian yang telah dilakukan. Produksi harian bahan isian yakni;

1. Produksi harian sampah makanan yakni $19,268 \mathrm{Kg} / \mathrm{Hari}$ atau 1115,355 L/Hari;

2. Produksi harian feses sapi yakni 350 $\mathrm{kg} / \mathrm{hari}$ atau 254 liter/hari.

Hasil pembentukan biogas menunjukkan biogas dengan kualitas bagus diperoleh dari digester uji 2 sedangkan biogas dengan kuantitas banyak diperoleh dari digester uji 1. Sehingga komposisi bahan isian digester uji 1 dan 2 dipertimbangkan untuk aplikasi. Alokasi bahan isian sesuai ketersediaan bahan yakni:

1. Komposisi sesuai digester uji 1 dapat dialokasikan untuk 66 digester $(501,6$ liter sampah makanan dan 158.4 liter feses sapi);

2. Komposisi bahan isian sesuai digester uji 2 dapat dialokasikan untuk 32 digester (163,2 liter sampah makanan dan 156,8 liter feses);

Aplikasi mengacu pada komposisi bahan isian digester uji 1 sejumlah 66 unit sesuai volume pada penelitian. Komposisi bahan isian sesuai digester uji 1 dipilih untuk diaplikasikan karena lebih memaksimalkan dalam pemanfaatan ketersediaan sampah makanan dan hasil yang akan diperoleh lebih banyak dari segi volume biogas untuk dikonversi menjadi energi listrik. Tabel 6 menunjukkan potensi listrik hasil konversi biogas.

Tabel 6. Potensi Energi Listrik Berdasarkan Ketersediaan Bahan Isian

\begin{tabular}{lccc}
\hline Digester & $\begin{array}{c}\text { kWh / } \\
\text { digester } \\
\text { (konversi) }\end{array}$ & $\begin{array}{c}\text { Alokasi Sesuai } \\
\text { ketersediaan } \\
\text { (digester) }\end{array}$ & $\begin{array}{c}\text { kWh } \\
\text { total }\end{array}$ \\
\hline Uji 1 & 0,522 & 66 & 34,459 \\
\hline Uji 2 & 0,582 & 32 & 18,637 \\
\hline
\end{tabular}

Perolehan hasil konversi biogas menjadi energi listrik yakni digester uji 1 menunjukkan angka yakni $34,459 \mathrm{kWh}$ setelah pengoperasian digester selama 20 hari.

Skenario Pengaplikasian Pemanfaatan Bahan Isian Untuk Menghasilkan Biogas di 
Kampus Unand. Jumlah biogas yang dihasilkan serta kualitas biogas juga menjadi bahan pertimbangan untuk pengaplikasian pengolahan sampah makanan untuk pembentukan biogas di kampus Unand.

Rencana pengembangan UPT Peternakan yakni menambah jumlah ternak sesuai kapasitas tampung yakni 100 ekor sapi sehingga feses yang dihasilkan 725 liter/hari. Pemanfaatan feses sapi didesain dengan pengalokasian 50:50 untuk kebutuhan UPT dan PPST Unand. Ketersediaan feses sapi yang dapat diolah oleh PPST Unand yakni 362 liter/hari yang direncanakan untuk proses pengomposan sejumlah 300 liter dan sisanya digunakan untuk pembentukan biogas sejumlah 62 liter. PPST Unand juga mendapatkan suplai feses sapi dari peternakan warga yang telah bermitra dengan pihak Unand. Feses sapi tersebut sejumlah $140 \mathrm{~kg} /$ hari setara $0,1 \mathrm{~m}^{3}$ dan direncanakan untuk dialokasikan untuk proses pembentukan biogas.

Desain aplikasi direncanakan pembangunan digester sejumlah 5 unit dengan volume masing-masingnya $1,5 \mathrm{~m}^{3}$. Hasil yang dapat diperoleh dari 1 digester aplikasi yakni biogas dengan volume 704,1 liter/ 20hari $\left(0,704 \mathrm{~m}^{3} / 20\right.$ hari) dan dikonversi menjadi 34,359 kWh/20 hari. Hasil yang dapat diperoleh dari 5 digester aplikasi yakni biogas dengan volume 4525,95 liter/20hari $\left(4,52 \mathrm{~m}^{3} / 20\right.$ hari) yang dapat dikonversi menjadi energi listrik sebesar 172,296 $\mathrm{kWh} / 20$ hari.

Penentuan volume digester aplikasi mempertimbangkan jumlah total bahan isian sekitar 914,1 liter sehingga masih terdapat ruangan untuk udara. Pemasokan bahan isian dilakukan diawal proses $100 \%$ untuk digester 1 pada hari pertama dan 100\% untuk digester 2 pada hari kedua dan seterusnya hingga digester 5 . Proses pengolahan anaerobik bahan isian ditunggu hingga 6 hari kemudian dilakukan pemasukan bahan setiap hari yakni $20 \%$ untuk masing-masing digester aplikasi.

Alokasi listrik yang diperoleh dari konversi biogas direncanakan untuk memenuhi kebutuhan listrik dalam operasional PPST Unand. pada unit pengolahan sampah yang dapat dilihat pada Tabel 7 .
Tabel7. Alokasi Pemakaian Listrik pada PPST Unand

\begin{tabular}{lcc}
\hline \multicolumn{1}{c}{ Alat Elektronik } & $\begin{array}{c}\text { Jumlah } \\
\text { (unit) }\end{array}$ & kWh/bulan \\
\hline Sealer impulse & 1 & 2,58 \\
\hline Lampu penerangan & 1 & 14,4 \\
\hline Pencacah plastik & 1 & 10,8 \\
\hline Pembilas plastik & 1 & 0,9 \\
\hline Ayakan & 1 & 44 \\
\hline Komposter & 5 & 247,5 \\
\hline Total & 10 & 320,18 \\
\hline
\end{tabular}

Daya yang diperlukan untuk memenuhi kebutuhan bulanan operasional unit pengolahan sampah sebesar $322,58 \mathrm{kWh}$ sedangkan energi yang dapat dihasilkan sebesar 172,296 kWh dalam selang waktu 20 hari pengoperasian digester. Kebutuhan listrik unit pengolahan sampah di PPST Unand belum dapat dipenuhi dengan menggunakan listrik hasil konversi biogas. Perhitungan kebutuhan listrik PPST Unand selama 20 hari dilakukan dan diperoleh nilai $216,755 \mathrm{kWh}$.

Rendahnya nilai konversi biogas ke energi listrik dikarenakan keterbatasan alat uji hidrokarbon untuk estimasi konsentrasi gas metana. Kemampuan pendeteksian konsentrasi hidrokarbon menggunakan alat ini sekitar 0-5\%. Hasil perolehan estimasi konsentrasi gas metana yang terkandung dalam biogas diantaranya $0,059 \%$ (digester kontrol), 1,550\% (digester 1) dan 2,330 (digester 2). Nilai tersebut sangat rendah apabila digunakan untuk dilakukan konversi ke energi listrik.

Alat dengan tingkat pendeteksian yang lebih tinggi diperlukan untuk perolehan estimasi gas metana yang lebih besar. Gas kromatografi merupakan salah satu alat dengan tingkat pendeteksian hingga 95\% tentunya akan menghasilkan nilai yang lebih akurat dibandingkan menggunakan alat absorbsi. Penggunaan gas kromatografi sebagai alat pendeteksi konsentrasi gas metana dalam biogas akan mempengaruhi perolehan nilai untuk konversi energi listrik.

Metode pengukuran menggunakan gas kromatografi dengan kemampuan deteksi yang lebih tinggi serta lebih spesifik untuk mendeteksi konsentrasi gas metana dalam biogas tentu akan menghasilkan nilai konversi energi listrik yang lebih besar dibandingkan metode absorbsi untuk mengetahui kandungan hidrokarbon 
sebagai acuan untuk estimasi konsentrasi gas metana dilakukan pada penelitian. Perolehan angka hasil konversi biogas ke energi listrik menggunakan metode absorbsi dengan kemampuan deteksi hidrokarbon sebesar $0-5 \%$ dapat menghasilkan nilai konversi listrik yakni 216,755 kWh. Sehingga dapat diperkirakan apabila pendeteksian konsentrasi gas metana dilakukan menggunakan gas kromatografi dengan kemanpuan deteksi hingga 95\% akan menghasilkan nilai konversi ke energi listrik yang lebih besar dan diperkirakan dapat mencukupi kebutuhan energi listrik di PPST Unand.

\section{KESIMPULAN}

Digester uji 1 (terpilih untuk aplikasi) menghasilkan biogas 13,715 liter dengan estimasi konsentrasi gas metana yakni $15502,61 \mathrm{mg} / \mathrm{L}$. Konversi biogas ke listrik yakni $0,552 \mathrm{kwH} / 20$ hari. Satuan produksi biogas digester uji 1 yakni 0,552 $\mathrm{kWh} / 20$ hari/7,6liter sampah makanan dan 2,4 liter feses sapi. Konversi biogas ke listrik berdasarkan ketersediaan bahan sesuai digester uji 1 yakni 34,359 kWh/66 digester bahan isian/20hari. Operasional 5 digester aplikasi menghasilkan listrik 172,296 $\mathrm{kWh} / 20$ hari.

\section{DAFTAR PUSTAKA}

Al Seadi, T. 2008. Biogas Handbook. BiG>East project. ISBN 978-87992962-0-0. University of Southern Denmark Esbjerg, Niels Bohrs Vej 910, DK-6700 Esbjerg, Denmark.

Arsova, L. 2010. Anaerobic Digestion Of Food Waste: Current Status, Problems And An Alternative Product Department of Earth and Environmental Engineering $\mathrm{Fu}$ Foundation of Engineering and Applied Science Columbia University.

Berita Unand, 2014. Unand Menuju Green Campus. Universitas Andalas: Padang.
Berutu, Romadani. 2014. Studi Potensi Ketersediaan Hijauan di Lahan Universitas Andalas Kampus Limau Manis. Fakultas Peternakan Universitas Andalas Padang.

Chania, V. 2010. Studi Timbulan, Komposisi dan Potensi Daur Ulang Sampah Kampus Unand Limau Manis. Jurusan Teknik Lingkungan Fakultas Teknik Universitas Andalas.

Culp, W. Jr. Archie. 1977. Prinsip Konversi Energi. Terjemahan Ir Darwin Sitompul, M.Eng, USU.

Lestari, R., A. 2012. Uji Pembentukan Biogas Dari Sampah Sayur dan Buah Dengan Penambahan Limbah Cair Tahu Tanpa Pengkondisian Lingkungan Digester. Tugas Akhir, Teknik Lingkungan, Universita Andalas: Padang.

PPST Unand. 2015. Pusat Pengolahan Sampah Terpadu, Universitas Andalas.

Raharjo, Slamet. 2012. Studi Pemanfaatan Sampah di Universitas Andalas. Jurusan Teknik Lingkungan: Unand.

Rosilawati, S. 2010. Pengaruh Waktu Tinggal Dan Komposisi Bahan Baku Pada Proses Fermentasi Limbah Cair Industri Tahu Terhadap Produksi Biogas. Fakultas Teknik Program Magister Teknik Kimia Universitas Sumatera Utara, Medan.

Tchobanoglous, George. 1993. Integrated Solid Waste Management. McGrawHill. California.

UPT Peternakan, 2014. Unit Pelaksana Teknis Peternakan. Fakultas Peternakan: Universitas Andalas.

Wahyuni, S. 2011. Menghasilkan Biogas dari Aneka Limbah. AgroMedia Pustaka: Jakarta. 
Wardana, 2012. Sampah Untuk Energi: Kelayakan Pemanfaatan Limbah Organik Dari Kantin di Lingkungan Universitas Diponegoro Bagi Produksi Energi Dengan Menggunakan Reaktor Biogas Skala Rumah Tangga. Program Studi Teknik Lingkungan Fakultas Teknik. Undip : Semarang.
Waskito, Didit. 2011. Analisis Pembangkit Listrik Tenaga Biogas Dengan Pemanfaatan Kotoran Sapi di Kawasan Usaha Peternakan Sapi. Tesis. Fakultas Teknik Program Magister Teknik Manajemen Energi dan Ketenagalistrikan. Universitas Indonesia. 